\title{
Kanuni Sultan Süleyman'ın Son Seferi Üzerine Bir Macar Kroniği: Bánffy György, “Második János ... török császárhoz menetele / II. János'un Türk İmparatoru'nu ziyareti"*
}

\section{A Hungarian Chronicle on the Last Campaign of Sultan Suleiman the Lawgiver.}

\author{
Kutse Altın' (D)
}

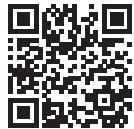

\footnotetext{
* Makale Szeged Üniversitesi Orta ve Erken Yeni Çağ Macar Tarihi Bölümü ve Köprülüler Restorasyonu Döneminde İmparatorluk Siyaseti ve Günlük Hayat projesi (OTKA-K 109070) ve Macar ilim Akademisi - Szeged Üniversitesi Osmanl Cŭ Arstırma

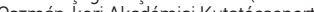
Oszmàn-kori Akademiai Kutatócsoport kapsamında hazırlanmıştı. Çalışmamı destekleyen Dr. Éva Kincses Nagy'a (Szeged Üniversitesi Altayistik Çalışmaları Bölümü Öğretim Üyesi) ve Prof. Dr. Sándor Papp'a teşekkürü borç bilirim.
}

'Sorumlu yazar/Corresponding author: Kutse Altın,

Department of Early Modern History, Faculty of Arts, University of Szeged, Hungary E-posta: kutsealtin@hotmail.com ORCID: 0000-0002-7334-6219

Başvuru/Submitted: 15.07.2020 Revizyon Talebi/Revision Requested: 17.08.2020

Son Revizyon/Last Revision Received: 04.09.2020

Kabul/Accepted: 08.09 .2020

Atıf/Citation: Altin, Kutse, “Kanuni Sultan Süleyman'ın Son Seferi Üzerine Bir Macar Kroniği: Bánffy György, “Második János ... török császárhoz menetele / II. János'un Türk Imparatoru'nu ziyareti"”, Güneydoğu Avrupa Araştırmaları Dergisi, 34 (2020), s. 27-44.

https://doi.org/10.26650/gaad.20213402

\section{öz}

Kanuni Sultan Süleyman'ın son seferi sadece siyasi ve askeri cihetleriyle değil, aynı zamanda kahramanlık anlatılarıyla da hem akademik hem de kamusal alanlarda detaylı bir şekilde tartışılmıştır. Bu makale ise dönemin narratif kaynaklarından biri olan "Második János ... török császárhoz menetele/ II. János'un Türk Imparatoru'nu ziyareti” nin Türkçe çevirisini sunmaktadır. Bu eserin János Zsigmond Szapolyai'nin kabulü sırasında otağ-ı hümayunun içerisine girdiğine inanılan dokuz Macar danışman arasında bulunan Bánffy György tarafından yazııdığı düşünülmektedir. Söz konusu kronik, Szigetvár seferi evvelinde II. Maximilian ve János Zsigmond Szapolyai arasında yaşanan çatışmalar ile bu çatışmaların Macar tarafındaki yansımaları hakkında kıymetli bilgiler sunmaktadır. Ayrıca, Bánffy György, János Zsigmond Szapolyai'nin kabulü için hazırlanan töreni de oldukça detaylı ve Osmanlı ve Macar diplomasisinin dinamiklerini son derece canlı bir biçimde betimleyen bir üslupla inşa etmektedir. György Bánffy metinde sık sık Sultan Süleyman'ın János Zsigmond Szapolyai'e karşı müsâmaha gösteren, hoşgörülü ve neredeyse babacan bir tavırla onu koruması altına aldığı ifade eden davranışlarına vurgu yapmaktadır. Bu nedenle metnin okuyucularının zihninde, György Bánffy'in sözleri ile, "her türlü kötülük pınarının başı olarak gösterilen Türklerin aslında baștan beri yardımcı olmak ve halkın çıkarlarını korumak dışında bir şey yapmadıkları" algısını oluşturmayı da hedeflediği düşünülebilir.

Anahtar Kelimeler: Osmanlılar, Macarlar, Habsburglar, Szigetvár Seferi, Naratif Kaynaklar

\section{ABSTRACT}

The last campaign of Kanuni Sultan Süleyman has been broadly discussed in both the academic and public spheres, not just in terms of its political and military aspects but also by virtue of its heroic narratives. This paper 
presents the Turkish translation of a narrative source "Második János ... török császárhoz menetele / John the Second...visit to the Turkish Emperor." This chronicle is assumed to have been written by Bánffy György, who was among the nine Hungarian advisors that were taken into the imperial tent during the reception of János Zsigmond Szapolyai. The chronicle of Bánffy provides valuable information about the conflicts between Maximilian II and János Zsigmond Szapolyai prior to the Szigetvár campaign and the reflections of those conflicts on the Hungarian side. Furthermore, Bánffy György reconstructs the ceremonies of the reception of János Zsigmond in a very elaborated style that vividly reflects the dynamics of Ottoman and Hungarian diplomacy.

Keywords: Ottomans, Hungarians, Habsburgs, The Siege of Szigetvár, Narrative Sources

\section{EXTENDED ABSTRACT}

It was the year 1566 when the Ottoman army, led by Sultan Suleiman the Lawgiver (1494-1566) in person for the last time, advanced towards Hungary to intervene in the long-standing turmoil between the Habsburg Emperor Maximilian II (1527-1576), and John Sigismund Szapolyai (1540-1571). When the Ottoman army reached Belgrade, a reception was organized at Zimony (present-day Zemun in Serbia) on behalf of the ruler of Transylvania. A noble order (nâme-i şerif) had been sent to John Sigismund Szapolyai, who was referred to as "the son of the King" in Ottoman sources, and he was summoned to the imperial tent. After a few days of preparations, he boarded ships that had been sent for him and joined the Ottoman army in Zimony. Sultan Suleiman's final campaign to Szigetvár has been widely discussed in academia in terms of its political and military aspects. Moreover, the narrative elements of the Szigetvár campaign, such as Sultan Suleiman's final journey to the battlefield, his old age and illness, his death just before the end of the siege, grand vizier Sokollu Mehmed Pasha's efforts to conceal the death of the Sultan Suleiman from the janissary army, and the burial and funeral of the Sultan are hot topics of popular culture. This paper presents the Turkish translation of a narrative source entitled "Második János ... török császárhoz menetele / John the Second...visit to the Turkish Emperor" written by György Bánffy, who was one of John Sigismund Szapolyai's nine advisors who were believed to have entered the imperial tent of Sultan Suleiman. The chronicle was edited by József Bessenyei and the introductory text and footnotes were prepared by him. Even though the writer of the chronicle is not precisely known, József Bessenyei claims that the chronicle was written by György Bánffy, and this view has been accepted and not challenged up to this time. Második János ... török császárhoz menetele not only provides the details of events but also presents information about the Hungarian nobility and officials of the period. The ruler of Transylvania visited Sultan Suleiman with an experienced group of nobles that served the Hungarian kingdom for a long time and whom György Bánffy mentions one by one in his text. In the first part of the chronicle, he provides a significant picture of the conflicts between Maximilian II and John Sigismund Szapolyai prior to the Szigetvár campaign and the reflections of those conflicts on the Hungarian side. According to György Bánffy, it was Maximilian II who betrayed the prince of Transylvania. Consequently, 
both the Hungarian ruler and the nobles were openly concerned about the slanders that could arise in the Ottoman court and could infuriate the Ottoman ruler. Therefore, John Sigismund Szapolyai, who was sure that the Sultan was provoked by the Habsburg ruler, was seeking ways to reverse the situation. In the second part, he shares details about the decision of the Ottoman ruler to embark on a military campaign, the order John Sigismund Szapolyai had established before he went to the imperial tent, his journey, and his presence before Sultan Suleiman. György Bánffy reconstructs the ceremonial reception of John Sigismund Szapolyai in a very elaborate style which reflects the dynamics of Ottoman and Hungarian diplomacy quite vividly. In the text, György Bánffy frequently stresses the sympathy of Sultan Suleiman and his almost fatherly protection of John Sigismund Szapolyai. Such indications of affection may have been constructed to emphasize and internalize the support that the Hungarians required from the Ottomans to take a stand against the Habsburgs. It is possible to think that they wanted to demonstrate to the reader of the era that the support they could receive from the Ottomans was not only military protection from a powerful emperor but also moral support that a father would provide to his young son. Besides, the text may have also aimed to create a perception in the minds of the readers that "... although they point to the Turks as the head of the fount of every kind of evil, the Turks did not do anything but help and protect the interests of the people, since the beginning." 


\section{Kanuni Sultan Süleyman'ın Son Seferi Üzerine Bir Macar Kroniği: Bánffy György, “Második János ... török császárhoz menetele / II. János'un Türk İmparatoru'nu ziyareti"}

Kanuni Sultan Süleyman'ın son seferi siyasi ve askeri cihetleri bağlamında pek çok akademik çalışmanın odak noktası, içerisinde barındırdığı dramatik kırılma noktaları ve kahramanlık hikayeleri açısından da hem Macar hem de Türk toplumunun kültürel hafızasının bir parçası olmuştur. ' Yüzyıllar boyunca muhafaza edilecek 'altın çağ' paradigmasının meşru simgesi Sultan Süleyman bu sefer sırasında vefat etmiş, son nefesine kadar savunmayı bırakmayan kale kumandanı Miklós Zrínyi ise verdiği mücadeleyle destanlara konu olan ulusal bir kahraman haline gelmiştir.

Sefere 29 Nisan 1566 tarihinde çıkılmış, Kanuni Sultan Süleyman'ın otağı Edirnekapısı'nın dışına kurulmuş, asker de Rüstem Çelebi Çiftliği'nde konaklamıştır. ${ }^{2}$ Sigetvar seferini konu alan Feridun Ahmed Bey'in Nüzhet-i esrârü'l-Ahyâr der-Ahbâr-ı Sefer-i Sigetvar, Âgehî'nin Fetih-nâme-i Kal'a-i Sigetvar ve Selaniki Mustafa Efendi‘nin, Tarih-i Selaniki gibi Osmanlı kronikleri padişahın ilerlemiş yaşına rağmen bizzat iştirak ettiği bu son seferin gerekçeleri arasında Habsburg hükümdarının geciktirdiği vergiyi, Erdel vilayetine ait yerlerde bazı hisarları kuşatmasını ve Budun yollarındaki, Göle (Gyula), Eğri (Eger) ve Sigetvar (Szigetvár) hisarları çevresindeki haydutların müslüman halka zulmetmesini saymaktadırlar. ${ }^{3} 1564$ yılında Habsburg kralı I. Ferdinand'ın ölümünün ardından II. Maximilian'ın tahta geçmesiyle beraber,

1 Pál Fodor, Szabolcs Varga, "Zrínyi Miklós és Szulejmán halála", Történelmi Szemle 58/2 (2016), 181-201; Pál Fodor (ed.), The Battle for Central Europe. The Siege of Szigetvár and the Death of Süleyman the Magnificent and Nicholas Zrínyi (1566) (Leiden-Boston: Brill; Budapest: Hungarian Academy of Sciences Research Centre for the Humanities, 2019); Pál Fodor, The Unbearable Weight of Empire - The Ottomans in Central Europe - A Failed Attempt at Universal Monarchy (1390-1566) (Budapest: Research Centre for the Humanities, Hungarian Academy of Sciences, 2015), 129-133; M.Tayyip Gökbilgin, “Kanuni Süleyman'ın 1566 Szigetvar Seferi Sebepleri ve Hazırlıkları”, Tarih Dergisi 21 (1966), 1-14; M.Tayyip Gökbilgin, “Nagy Szolimán 1566. évi Szigetvár elleni hadjáratának előzményei", Szigetvari emlekkönyv. Szigetvár 1566. évi ostromának évfordulójára içinde, Ruzsás Lajos (ed.) (Budapest: Akadémiai Kiadó, 1966), 53-59; M.Tayyip Gökbilgin, Kanuni Sultan Süleyman (İstanbul: Trakya Üniversitesi, 2016), 143-147; Pap Norbert (ed.), Szülejmán Szultán emlékezete Szigetváron/Kanuni Sultan Süleyman'ın Sigetvar'daki hatırası (Pécs: Mediterrán és Balkán Fórum,VIII. évfolyam, 2014); Zeynep Tarım Ertuğ, "Minyatürlü Yazmaların Tarihî Kaynak Olma Nitelikleri ve Nüzhetü'l-esrâr," Tarih Boyunca Türk Tarihinin Kaynakları Semineri 6-7 Haziran 1996 Bildiriler içinde, (İstanbul, 1997), 31-46; Fatih Başpınar, "Kanuni Sultan Süleyman'ın Son Seferine Dair Bir Mesnevi: Merâhî'nin “Fethnâme-i Sefer-i Sigetvar" Adlı Eser”, Dede Korkut Türk Dili ve Edebiyatı Araştırmaları Dergisi II/4 (2013), 18-74; Şebnem Parladır, "Sigetvar Seferi Tarihi ve Nakkaş Osman", Sanat Tarihi Dergisi XVI/1, (2007), 67-108; Hüseyin Gazi Yurdaydın, "Sigetvarnâmeler", Ankara Üniversitesi Ilahiyat Fakültesi Dergisi, II-III, (1952), 124-136; James Tracy, "The Road to Szigetvár: Ferdinand I's Defense of His Hungarian Border, 1548-1566.", Austrian History Yearbook, 44, (2013), 17-36; Szabolcs Varga, Europe's Leonidas: Miklós Zrínyi, Defender of Szigetvar (1508 - 1566), çev. David Robert Evans (Budapest: Research Center for the Humanities, Hungarian Academy of Sciences, 2016), 224-248.

2 Başbakanlık Osmanlı Arşivleri (BOA), 5 Numaralı Mühimme Defteri, 973 / 1565-1566, no.1500. (Ankara: 1994); [Selaniki Mustafa Efendi], Tarih-i Selaniki, Mehmet Ipşirli (ed.), (istanbul: Edebiyat Fakültesi Basımevi, 1989), 16.

3 [Feridun Ahmed Bey] Nüzhet-i esrârü'l-Ahyâr der-Ahbâr-I Sefer-i Sigetvar, Sultan Süleyman'in Son Seferi, ed. H. Ahmet Arslantürk - Günhan Börekçi, tıpkıbasım (İstanbul: Zeytinburnu Belediyesi Kültür Yayınları, Kitap No: 26, 2012), 88-93. 
Osmanlılar Habsburgların elindeki Macar Krallığı toprakları için ödenmesi gereken fakat uzun süredir ihmal edilen vergiyi talep ederler. Bu dönem yine Habsburg İmparatorluğu'nun Erdel vilayetine tabii toprak ve hisarlara taarruzda bulunması sonucu ortaya çıkan karışıklığa dair gönderilen emirler ve yapılan yazışmalar da kronikleri destekler niteliktedir. ${ }^{4}$ Aslına bakılırsa söz konusu sıkıntılar, taraf değiştirip Kral I. Ferdinand yanlısı olan Macar asilzadesi Balassa Menyhért'in 1562 yılında Tokaj bağlarının hasatına el koyması ile ortaya çıkar. Bunun üzerine János Zsigmond Szapolyai, naibi ve kumandanı István Báthory'i görevlendirerek Szatmár ve Nagybánya'yı ele geçirir. 1565 yılına gelindiğinde II. Maximilian'ın kumandanı Lazarus von Schwendi, önce Tokaj ardından Szatmár, Erdőd ve Nagybánya'yı Erdel Prensliğinden geri alır. ${ }^{5}$ Bu sırada Habsburg elçileri Alberto de Wyss ve (Michael) Mikel Černović (Cernovith) İstanbul'da sulh koşullarının muhafazası için müzakereler yürütür; ${ }^{6}$ eksik kalan vergiler gönderilir ${ }^{7}$ fakat Lazarus von Schwendi'nin Şubat ayının dokuzunda Tokaj'ı zapt etmesii Osmanlı tarafında güvensizliklerin artmasına sebebiyet verir.?

Bu zaman zarfında, Erdel prensinden acil yardım ricaları doğrultusunda gelen mektuplar üzerine, Temeşvar beylerbeyi Mustafa Paşa ve Budin beylerbeyi Arslan Paşa yardıma gönderilir. ${ }^{10}$ Temeşvar beylerbeyinin müdahalesi ile 1565 yılının Ağustos ayında önce Erdőd ardından da Szilágycseh, Nagybánya ve Szatmár alınır. İki tarafın elçileriyle yapılan müzakereler sonucunda sulha karar verildiği ve bu karar neticesinde Temeşvar beylerbeyi ile János Zsigmond Szapolyai kendi bölgelerine döndüğü halde, Nemçelilerin geri çekilmiş gibi davranıp aslında

4 Claudia Römer ve Nicolas Vatin. “The Hungarian Frontier and Süleyman's Way to Szigetvár according to Ottoman Sources." The Battle for Central Europe içinde, 341-358; Anton C. Schaendlinger ve Claudia Römer, Die Schreiben Süleymans des Prächtigen an Vasallen, Militärbeamte, Beamte und Richter aus dem Haus-, Hof- und Staatsarchiv zu Wien, tıpkıbasım, "Urkunde 39", "Urkunde 33a” (Wien: Verlag der Österreichischen Akademie der Wissenschaften, 1986), 57-58, 68-69; Anton C. Schaendlinger ve Claudia Römer: Die Schreiben Süleymans des Prächtigen an Karl V., Ferdinand I. und Maximilian II. aus dem Haus-, Hof- und Staatsarchiv zu Wien, tıpkıbasım, "Urkunde 25", “Urkunde 27", “Urkunde 32", “Urkunde 33”,“Urkunde 34”,"Urkunde 35” (Wien: Verlag der Österreichischen Akademie der Wissenschaften, 1983), 67-70, 76-77, 87-100; Gisela Procházka-Eisl ve Claudia Römer, Osmanische Beamtenschreiben und Privatbriefe der Zeit Süleymāns des Prächtigen aus dem Haus-, Hof- und Staatsarchiv zu Wien, belge no: 69, 70 (Wien: Verlag der Österreichischen Akademie der Wissenschaften, 2007); Feridun Ahmed Bey, Mecmua-i Münşeatü ‘s-selatin (İstanbul: Takvimhane-yi Âmire Matbaası, 1265-1274/1848-1858), 2:89-90, https://acikerisim.tbmm.gov.tr/xmlui/handle/11543/588, (Erişim 23 Mayıs 2019).

5 James D. Tracy, “Tokaj, 1565: A Habsburg Prize of War and an Ottoman Casus Belli”, The Battle for Central Europe içinde, 359-376; Ferenc Forgách, Emlékirat Magyarország állapotáról Ferdinánd, János, Miksa királysága és II. János erdélyi fejedelemsége alatt, çev., Borzsák István,(Budapest: Szépirodalmi Könyvkiadó, 1982), 231-241; Bánffy György, “Második János ... török császárhoz menetele"” Zay Ferenc, János király árultatása. Kis Péter: Magyarázat.[Bánffy György]: Második János ... török császárhoz menetele, ed.Bessenyei József (Budapest: Balassi Kiadó, 1993), 119-121.

6 Özgür Kolçak, “Sınır Diplomasisinden Saltanat Elçiliğine: Bir 16. Yüzyil Diplomasi Hikâyesi Yahut Marcus Scherer/ Hidayet'in Esrarli Sergüzeşti”. Tarih Araştırmaları Dergisi 39 (2020), 166-173.

7 Schaendlinger ve Römer, Die Schreiben Süleymans des Prächtigen an Karl V., Ferdinand I. und Maximilian II. aus dem Haus, “Urkunde 33”, 17 Şubat 1565 tarihli belge.

8 Bánffy, Második János, 113.

95 Numaralı Mühimme Defteri, no: 259, 260, 278; Eduard Wertheimer, "Zur Geschichte des Türkenkrieges Maximilians II. 1565 und 1566", Archiv für österreichische Geschichte 53 (1875), 43-101; Kolçak, "Sınır Diplomasisinden Saltanat Elçiliğine", 170-172.

10 Gökbilgin, “Kanuni Süleyman'ın 1566 Szigetvar Seferi”, 3-4; 5 Numaralı Mühimme Defteri, no: 54, 99, $108,154$. 
hala teyakkuzda oldukları haberleri alınmaktadır."1 Habsburg kralının, Erdel'den aldıkları kalelerden vazgeçtiklerini bildiren bir elçi göndermesi ve hemen ardından Osmanlı tarafından gönderilen name-i hümayunda yazılı hususları kabul ettiğini ${ }^{12}$ bildirmesine rağmen Lazarus von Schwendi'nin geri çekilmeye niyetinin olmadığına dair bir mektup da ele geçirilmiştir. ${ }^{13}$ Osmanlı askerinin çekilmesinin ardından Nemçe ordusunun Nagybánya ve Szilágycseh'i kuşatıklarına ilişkin malumat da hem János Zsigmond, hem de Temeşvar beylerbeyi tarafından Bâb-I Âli'ye bildirilmiştir. ${ }^{14}$

Öte yandan, bütün bunlara ek olarak Habsburg İmparatoru II. Maximilian'nın, Sultan Süleyman'a, Erdel prensinin kendisiyle ona haber vermeden bir anlaşma yapma niyetinde olduğuna ilişkin malumat içeren yazışmaları da ilettiği ve bunu haber alan János Zsigmond'un kendisini sultanın karşısında müdafaa etmek ve artan Habsburg baskısı karşısında sarayın müdahalesini hızlandırmak gayesiyle İstanbul'a gitmek için izin istemesi de Macar kroniklerinde rastlanılan bir konudur. ${ }^{15} \mathrm{Bu}$ arzusu topraklarındaki karışıkliğa istinaden reddedilmiş; hemen ardından, söz konusu kargaşaya bizzat müdahale etmek için Osmanlı birliklerinin ilkbaharda sefere çıkmasına karar verilmiştir. ${ }^{16}$

Sefere çıkılması ve Sultan Süleyman'ın ahvali Osmanlı kroniklerinde oldukça görkemli bir biçimde tasvir edilmektedir. Bunlara göre, sultanın kendisi de dahil olmak üzere ordusunun her bir unsuru mükemmeldir. ${ }^{17}$ Sultan belli bir müddet "yir piyade yürüyüp" ardından yola arabayla devam etmiş, Sokollu Mehmet Paşa durup dinlenmeden bir menzil öne gidip Sultan Süleyman'ı rahat ettirmek için araba yollarını denetlemiştir. ${ }^{18}$ Belgrad'a 49 günde varııdığını yazan Selaniki'yi, Kocaili beyine yazılan, ordunun 19 Haziran günü Belgrad'da konakladığını bildiren hüküm de doğrular. ${ }^{19}$ Sava nehrinin sularının yükselmesi sonucunda köprü kurulabilecek en uygun yer olan Böğürdelen (Szabács) Kalesi yakınlarında çalışmalar yapıımış ${ }^{20}$, Agehi'nin verdiği tarihe göre 27 Haziran'da Zemun nam kaleye otağ-ı hümayun kurulmuştur. ${ }^{21}$ Bu tarihten altı gün evvel, Osmanlıların sıklıkla "Kral oğlu" olarak zikrettiği János Zsigmond'a name-i şerif gönderilerek Balçık denilen bölgeye gelmesi, birkaç gün bekleyip kendisine tahsis edilecek gemilerle Zemun'a (Zimony) geçip orduya katılması istenmiştir. ${ }^{22}$

11 Bánffy, Második János, 119-120; Procházka-Eisl ve Römer, Osmanische Beamtenschreiben und Privatbriefe der Zeit Süleymāns des Prächtigen aus dem Haus, No: 99, 1565 tarihli belge; 5 Numaralı Mühimme Defteri, no: 331, 332.

12 Tracy, “Tokaj, 1565”, 370; 5 Numaralı Mühimme Defteri, no: 259, 260

135 Numaralı Mühimme Defteri, no: 332.

145 Numaralı Mühimme Defteri, no: 491, 492, 493.

15 Bánffy, Második János, 120.

165 Numaralı Mühimme Defteri, no: 330.

17 Kübra Naç, “Âgehî̉nin Fetih-nâme-i Kal'a-i Sigetvar'ı (İnceleme-Tenkitli Metin)” (Yayınlanmamış Yüksek Lisans Tezi, Fatih Üniversitesi, 2013), 139-140; İpşirli, Tarih-i Selaniki, 14-15.

18 Arslantürk ve Börekçi, Nüzhet-i esrârü'l-Ahyâr der-Ahbâr-ı Sefer-i Sigetvar, 98; İpşirli, Tarih-i Selaniki, 18.

19 İşirli, Tarih-i Selaniki, 19; 5 Numaralı Mühimme Defteri, no: 1954.

205 Numaralı Mühimme Defteri, no: 1747, 1757, 1784, 1790, 1871, 1923; Arslantürk ve Börekçi, Nüzhet-i esrârü'lAhyâr der-Ahbâr-ı Sefer-i Sigetvar, 99.

21 Naç, "Âgehî'nin Fetih-nâme-i Kal'a-i Sigetvar'", 148; 5 Numaralı Mühimme Defteri, no: 1977, 1981.

225 Numaralı Mühimme Defteri, no: 1987; Bánffy, Második János, 124-125. 
Hem Osmanlı kroniklerinde hem de Macar kroniklerinde János Zsigmond Szapolyai'nin kabulüne ilişkin detaylı bilgiler bulunmaktadır. Benim burada sunacağım kaynağın önemi de burada yatmaktadır. Bu kronik József Bessenyei ${ }^{23}$ tarafından derlenmiş; metinler düzenlenmiş, giriş metni ve dipnotları hazırlanmıştır. Aslına bakılırsa kroniği kimin kaleme aldığı net olarak bilinmemektedir. Kroniğin Bánffy György'e ait olduğunu iddia eden, metni derleyip düzenleyen József Bessenyei'dir ve bugüne kadar bu görüşe karşı çıkılmamıştır. Söz konusu kronik salt o dönemde gerçekleşen hadiselerin detaylarına yer vermekle kalmaz; aynı zamanda bize dönemin Macar asilzadelerine ve devlet adamlarına ilişkin de malumat verir. Erdel prensi Türk hükümdarının yanına uzun zamandır gerek aile gerekse kilise bağlarıyla Macar devletinin hizmetinde yer alan bir kadroyla birlikte gitmiştir. Bánffy György bu isimleri tek tek sayar. Metnin dipnotlar kısmında bu kişilerin hizmetlerine dair kısa özetler hazırlamaya çalıştım. Macar akademisyenleri tarafından sık sık referans verilen bu kroniği Türk okuyucularına da sunabileceğimiz için kıvanç duyuyoruz.

Haşmetli prensim geçen sene, yüzlerce ve binlerce Almanı topyekun kılıçtan geçirdikten sonra Bánya ${ }^{24}$ ve Cseh'i ${ }^{25}$ bir yandan güç ve diğer yandan hileyle zapt eyledi. Ordusunu teyakkuza geçirerek Tisza'nın kıyısında karargah kuran Alman ordusuna baskın yapıp savaşmayı emretti. Lakin savaş başlamadan evvel biri Türk ordusundan diğeri İmparator Maximilian'dan iki elçi geldiği vakit tüm umutlar yok oldu. Çünkü imparatorun ve sultanın paşalarının emriyle harekatın durdurulup, ordunun geri döndürülmesi emredilmişti. Maximilian'la daha evvel gasp ettiği yerleri haşmetli prense geri vereceği şartıyla ateşkes anlaşması yapıldı. Maximilian verdiği sözü elçileri yoluyla Türk sultanına bildirdi. Diğer bir elçi de aynı emri Lazarus²6 ve Almanların liderine 27 iletti.

Elçileri işitince haşmetli prens Erdel'e, paşa ise Temesvár'a ${ }^{28}$ geri döndü. Almanlar süvarilerin bir kısmını gönderip geri çekilmiş gibi davrandılar ancak Türklerin çekilmesinin hemen ardından, müstakbel bir sulhun ümidiyle, kalesiyle beraber harabeye dönen Bánya'ya gizlice girip orayı ele geçirdiler. Viran olmuş Cseh'i de alıp, Munkács'a29 girdiler ve orada konaklayacaklarını duyurdular.

23 Zay Ferenc, János király árultatása; Kis Péter: Magyarázat, [ Bánffy György:] Második János ... török császárhoz menetele, ed. Bessenyei József (Balassi Kiadó, Budapest, 1993).

24 Nagybánya (günümüzde Baia Mare, Romanya.)

25 Szilágycseh (günümüzde Cehu Silvaniei, Romanya.)

26 Lazarus von Schwendi (1522-1584) 1546 yılında V. Karl'ın hizmetine giren Schwendi, 1555 yılından itibaren II. Philip'in ordusunda görev aldı. 1564 yılında İmparator II. Maximilian'ın Macarsitan'daki ordularının kumandanıydı. 1568 yılında yapılan Edirne Anlaşması'dan ardından Hohenlandsberg Baronu ünvanı bahşedilmiş ve görevinden ayrılmıştır.

27 Burada yazarın Viyana Savaş Konsilinin başkanından bahsettiği düşünülmektedir.

28 Günümüzde Timișoara, Romanya.

29 Günümüzde Mukachevo, Batı Ukrayna. 
Haşmetli prens meseleyi idrak edip, Türk sultanına anlaşmanın ihlal edildiğini bildirdi. Maximilian'ın kış vakti, tayın yokken ve ordunun yardımı da tükenmek üzereyken sözünden dönmesine hayli öfkelenen sultan, imparatorun, kendi yanında bulunan iki elçisini zindana atıp, en kısa zamanda öç alacağına dair ant içti.

\section{Haşmetli Prens İhanete Uğradı}

Bunun üzerine Maximilian, sultanın öfkesini dindirmek isteyerek, üçüncü bir elçi vasıtasıyla haşmetli prense karşı ağır ithamlarda bulunup, her konuda onu suçladı. Sultanın kalbini kolayca kazanabilmek için tüm müzakereleri, elçilik belgelerini ve eski mektupları göndererek, onu prensin tavsiyelerinden ve arzularından haberdar edip, bundan böyle yüce sultandan, János Kral'ın oğlunu maslahat ve meselelerinde himaye etmemesi ricasında bulundu ve János'u gözden çıkarması halinde yaptıkları ittifaka ve kaidelere bağlı kalmaya hazır olduğunu bildirdi. Bu ve bilumum mesele hakkında malumat veren Maximilian, haşmetli prens tarafından birkaç sene evvel gönderilen tüm mektupları mülahaza etmesi için Türk sultanına yolladı.

\section{Sultanın Cevabı}

Sultanın mektupları okuyup, kralın vaatlerinin tesiri altında kalmaması mümkün değildi. Paşalarını çağırıp, işte hristiyan krallarının birbirlerine nasıl sözler verdiklerine bir bakın dedi. Eğer Maximilian bizi aldatmamış olsaydı, kesinlikle ona inanır ve oğlumuz János hakkında şer ithamlarda bulunurduk; lakin onun babası Ferdinand'ın, János'u ve Kraliçe İsabella hanımefendiyi sık sık yalan sözlerle kandırdığını bildiğimizden, ona körü körüne inanmak istemiyoruz. Bundan ötürü, her şeyden evvel meseleyi etraflıca sınayıp, emin olalım.

0 yüzden, oğlumuza elçiler gönderip, Maximilian tarafından bize gönderilen tüm mektupları ve onun elçileri tarafından verilen tüm malumatı bildirmenizi size emrediyoruz. Bu meseleden ötürü büyük bir telaş içerisinde harekete geçen paşalar tüm mektupları ve Maximilian'ın elçilerinin kelamlarını da toplayarak haşmetli prense gönderdiler.

\section{Haşmetli Prensin Yaptığı İstişareler}

Prens, hainliği işitip, sadakatsizliği fark edince ne yapılması gerektiği konusunda istişarelerde bulundu. Mazeretleri ikna edici olmadığı için bu ithamları ortadan kaldırmak ve refaha çıkmak adına sultana gitmesi gerekiyordu, bu yüzden meclisini topladı. Ve tüm ülkeyi tehdit altına sokacak bu meseleyle ilgili maruzatını tafsilatıyla bildirip, herkeste şaşkınlık yaratan ülkenin ayakta kalmasını istiyorlarsa Türk sultanına gidilmesinin tek çare olduğuna ilişkin kararını asillere açıkça bildirdi. Sultanın kışkırtılı̆̆ını bilen bütün paşalar da aynı tavsiyeyi vermişti; aksi halde bu zavallı ülke Maximilian'ın müthiş hainliği yüzünden son felaketini yaşayacaktı. Hem prens hem paşalar hem de sultan, Maximilian'ın Macarların sonunu getirmeye bu kadar istekli ve hazır olmasına çok şaşırmışlardı. Çünkü sahip olmakla o kadar övündüğü taç aslında Macarlara aitti. 


\section{Ülkenin Yanıtı}

Meclis âzâsı bu meseleyi işitince prensin söylediklerine hak verip gitmesini tavsiye etmiş ve onunla beraber gönderilecek adamların ve hediyelerin listesini kayda geçirmişti. Bunun için beş yüz süvari, ülkenin en tepesindeki adamları, iki yüz piyade ve dörder dörder at koştukları üç yüz araba seçtiler. En nihayetinde, âzâlar vatanının sağ kalması adına hayatını ve mallarını feda etmekten kaçınmadığı için prense teşekkürlerini sundular.

\section{Prensin Sultana İkinci Sefareti}

Haşmetli prensim hemen hediyelerle birlikte sultana gönderilecek baş elçileri seçti. Hainlik öylesine büyüktü ki sırf elçiler tarafından giderilmesi mümkün değildi. Bu yüzden kendini yüz yüze savunup, masumiyetini ispat etmeye karar verdiğini bildirdi. Sultandan ne düşmanlarına ne de böylesi bir hainliği artık alışkanlık haline getirmiş olanlara inanmamasını isteyecekti. Kendisi de üçüncü gün ülkenin en mühim adamları ile birlikte onun yanına giderek, temsilciler aracılığılla dünyaya, sultanın kötü hadiselerin müsebbibi yahut hristiyan halkının düşmanı olmadığını tam aksine Maximilian'ın Macar halkına karşı kötü niyetler beslediği anlatacaktı. Sultan, prensin kendi iradesiyle bu kimseye müsamahası olmayan padişahın karşısına gidip, ağır bir şekilde cezalandırılmaya razı gelmesinden aslında böylesi büyük bir ithamın müsebbibi olmadığını anlayabilirdi. Davası işitildiğinde gönül rahatlığılla oraya gitmeyi bekliyordu. Her ne kadar mektuplar açıkça gösteriyor olsa da prens, Maximilian'la olağanüstü koşullar altında barış yapmak zorunda kaldığını anlattığı vakit yüce sultanın lütfu ve merhametiyle karşılanacaktı.

\section{Sultanın Cevapları}

Sultan, elçilerden prensin bu ani seyahat arzusunu işitince tüm insanlığa karşı kötülük işleyen bu Almanların hileci ve iftiracı olduklarını uzun zamandır bildiğini, o yüzden prensin onun merhametinden tereddüt edip, şüpheye düşmesinin uygun görülmeyeceği yanııını verdi. Dahası, yüce sultana göre böylesi bir vakitte prensin ülkesini bırakıp uzun yola çıkması münasip değildi ve ülkesinden uzakta olmasını fırsat bilen Almanların ona karşı ayaklanması ya da yeni bir işe girişmesi ihtimali de yüksekti. Bundan ötürü şimdi kaleleri ve hudutları güçlendirip, muhafaza etmek daha mühimdi. Yüce sultanın Macaristan'a geleceği sırada onu ziyaret etmesi daha münasip olacaktı.

Bunun üzerine sultan iki lütufta bulundu: birincisi, prensin tüm mazeretlerini iyi niyetle kabul etti, ikincisi ise, ona karşı gizli bir nefretle dolu olmadığını açıkça gösterdi. Çünkü kalbinde prense karşı bir öfke duysaydı, onun şimdi yapmak istediği ziyaretini erteletip, beklemeye karar vermezdi. Bu durum, sonbaharın sonunda gerçekleşecek olan ziyaret için prensi daha da yüreklendirdi. Uzun zamandır tehlikeli olarak addedilen bu seyahatinin olağanüstü dürüst bir sebebinin bulunduğu, ülkenin ayakta kalması ve hristiyanlık adına prensin kendi hayatını ve bahtını, inayet ve yücelikle feda ettiğini artık herkes kabul etmeli. Her ne kadar 
Alman krallar, her türlü kötülük pınarının başı olarak Türkleri gösteriyor olsalar da aslında Türkler baştan beri yardımcı olmak ve halkın çıkarlarını korumak dışında bir şey yapmadılar.

\section{Sultanın Prense İkinci Sefareti}

(1566) Illkbahar geldiğinde, Mart'ın son gününde sultan, prense bir elçi göndererek, bir at, altın sırmalı bir giysi ve incili ağır bir kılıç hediye etti. Bunun üzerine o gün tüm ordusuyla birlikte Macaristan'a doğru yola çıkan sultan, prense ona yapılan tüm kötülüklerin intikamını ve de bu zamana kadar kaybettiklerini geri almasının vaktinin geldiğini, buna hazır olmasını emretti. Paşalar da padişahın öfkesinin tamamen dindiğini dile getirerek, yüce sultanın divanına gerçekleştireceği ziyaret için onu yüreklendirdiler. Padişah Tuna'yı geçer geçmez prensin de sultanın şanını yüceltmek adına, söz verdiği gibi yola çıkmasını tavsiye ettiler. Pek çok kişinin tehlikeli addettiği bu yol aslında son derece faydalı ve tehlikeden âzâde olacaktı, dahası sultanın gözünde de bu mesele son derece mühim idi.

\section{Gitmeden Önce Erdel'de Kurduğu Düzen}

Haşmetli prens gidişinin daha makul ve ardında bıraktığı ülkesindeki işlerin daha emin olması için, rahmetli Tamás Varkucs ${ }^{30}$ yerine süvari ordusunun başına, hemen azimli bir adamı, Kristóf Hagymási ${ }^{31}$ hazretlerini kumandan olarak atayarak, kaleleri muhafaza etmesini ve gerekirse tüm ordu ve silahlarla düşmana karşı çıkarak ülkeyi savunmasını emretti. Kendisinin de Türk sultanının yanına gideceği için sürekli tetikte olması gerekiyordu. Prens'e Kristóf Báthory ${ }^{32}$ ve Gábor Majláth ${ }^{33}$ hazretleriyle beraber, iki bin paralı asker ve üç bin de piyade eşlik etti.

30 Tamás Varkucs (?-1566) Macar asilzâdesi Péter Pérenyi'nin hizmetinde 1541 yılında Eğri Kalesi'nin kumandanlığını yaptı. Bir süreliğine Vârad Piskoposu György Martinuzzi'nin hizmeti altında da görevlerde bulundu. Bkz. a.g.e., 29. dipnot, s. 149.

31 Kristóf Hagymási (?-1578) 1557-1564 yılları arasında Huszt (günüzmüde Ukrayna'da bir şehir) kumandanlığını yapmıştır. Ardından Erdel'de János Zsigmond'un ordusunun başkumandanlığını ayrıca bir süre Nagyvárad (günümüzde Oradea, Romanya) kumandanlığı da yapmıştır. Bkz. a.g.e., 30. dipnot, s. 149. Ayrıca Hagymási Ailesi için bkz. Nagy Iván, Magyarország családai czimerekkel és nemzékrendi táblákkal, https://www.arcanum.hu/ hu/online-kiadvanyok/Nagyivan-nagy-ivan-magyarorszag-csaladai-1/otodik-kotet-356E/hagymassy-csaladszent-girothi-es-beregszoi-35D5/ , (erişim 27 Şubat 2019)

32 Kristóf Báthory (1530-1581) Kraliçe İsabella'nın hizmetinde çeşitli görevlerde bulunduktan sonra János Zsigmond kendisini ordu kumandanlığına tayin etmiştir. 1571-1576 yılları arasında Nagyvárad kumandanlığı yapar. 1576 yılında kardeşi István Báthory'nin Erdel Voyvodalığının ardından Lehistan Kralı olarak seçilmesinden sonra Kristóf Báthory onun yerini almıştır. Bkz. a.g.e., 31. dipnot, s. 149. Ayrıca Báthory Ailesi için bkz. Petri Mór, Szilágy Vármegye Monographiája, http://mek.oszk.hu/04700/04750/html/143.html , (erişim 27 Şubat 2019).

33 Gábor Majláth (1532-1577) 1541 yılında Osmanlılara esir düşüp 10 yıl boyunca Yedikule zindanında tutulduktan sonra orada vefat eden bir dönem Kral Ferdinand'ın Erdel Voyvodalığını da yapmış István Maylád'ın oğludur. Babasının vefatından da evvel, 1547 yılında, I. Ferdinand tarafından baronluğa tayin edilmiştir. 1560 yılında János Zsigmond, Gábor Majláth'a Fogaras'daki topraklarını iade etmiş ancak Sultan Süleyman ile görüşmesinden çok kısa bir süre sonra Mayláth Fogaras'ı Zsigmond'a bırakmıştır. Bkz. a.g.e, 32. dipnot, s. 159. Ayrıca Majláth Béla, A Majláth-család nemzedékrendje (négy rajzzal), https://www.arcanum.hu/hu/online-kiadvanyok/Turul-turul-1883-1950-1/1888435B/1888-1-435C/1a-majlath-csalad-nemzedekrendje-negy-rajzzal-4364/, (erişim 27 Şubat 2019). 


\section{Prensin Yolculuğu}

Tüm meseleleri bu şekilde düzenleyen haşmetli prens, sultanın Haziran'ın 16. günü, Tuna'yı geçtiğini işitince, Fejérvár'dan ${ }^{34}$ yola çıktı. Tanrı'nın yardımıyla Deva üzerinden Mardsina'ya ${ }^{35}$, ardından da geceyi geçireceği Lugos'a geçti. 26 Haziran'da Nándorfejérvár'ın ${ }^{36}$ berisinde, Tuna'nın bir mil ilerisinde Pancsova'da karargah kurdu. Bu arada, sultana çavuşlar gidip, geliyordu; sancakbeyleri de gelip her türlü iltifatın sözünü verip, muhabbetle ziyaretini gerçekleştirdiği sırada ne yapması ve söylemesi gerektiğini öğrettiler.

Sonraki gün, 27 Haziran'da ise, sultan kendi gemisini prense göndererek, halkını bırakıp ülkesinin başııa hizmetkarları ile beraber karşı kıyıya geçmesini; çadırların, yiyeceklerin ve gereken diğer her şeyin hazırlandığını bundan ötürü, bizzat bir şey getirmesine veya başkalarıyla göndermesine gerek olmadığıı bildirdi. Prens, dört yüz asilzade ve atlarılla, süslü giysiler ve ziynetlerle gemiye binip Tuna'yı geçerken Nándorfejérvárlıların sayısız top atışlarıyla selamlandı. Öteki kıyıya vardıkları vakit sultanın halkı karşılarına çıktı. Yine aynı yerde sultanın tüm tebaası onu onurla karşıladı ve herkes büyük bir sevinçle doldu. Bu arada sultan meseleyi daha iyi gözleyebilmek için çadırını yüksek bir yere, János Hunyadi'nin biricik memleketi, eskiden Zemlin ${ }^{37}$ diye anılan yıkılmış kalenin yanına kurulmasını ve prensin onurlandırılarak, sultanın zatına yaraşır şekilde selamlanmasını emretti. Çadırı kurulan padişah, tüm meseleyi oradan hayretle izledi. Prensin geçit töreni öyle sükunetli ve gururluydu ki, sancakbeyleri, çavuşlar ve bütün asiller onu takip etmiş, yolun tamamı sayısız süvari birlikleriyle kaplanmıştı. Tepenin üzerine kurulan çadırının altına geldiklerinde, teşrifatçı, prense, sultanın işte o gördükleri çadırın orada olduğunu ve atı üstünde, başını padişaha doğru çevirip, eğerek Türk usulü selam vermesi gerektiğini söyledi. Prens bunu o kadar kusursuz bir şekilde yerine getirdi ki orada bulunan herkes Allah Allah nidaları atmaya başladı. Prensi gören sultanın çokça muhabbetli olduğu söylenmekte ama şimdi burada bu detayları vermenin yeri değil. Fakat sultanın prensi Macar Krallığı'na götürüp, onu taçlandırıncaya kadar bu işin ardını bırakmayacağını söylediğini kesin olarak biliyoruz. Bu cihetle prens karargaha, hazırlanan çadıra dönerek bahşedilen bu onur için teşekkür edip, herkesi gönderdi.

\section{Sultanın Sözü}

Sultan, aynı saatlerde, sonraki günlerde kendisi ve maiyetindekilerin kutlu bir işle meşgul olacakları için dinlenmeleri gerektiğine dair mesajını gönderdi. Tam yatıtıkları sırada, sultan kutlamalar için tüm toplara ve yeniçerilere atış yapmalarını emretti. Bundan sonra tüm askerlere teker teker yüz akçe hediye dağıııımasını buyurdu. Kimilerine yüzer bin verilen paşalar, elli bin alan beylerbeyleri ve otuz bin alan sancakbeyleri hariç, hediye alanların sayısı elli bin kişiydi. Ayrıca asker kulların hepsine de beşer yüz akçe verildi ki, bu da hiç kuşkusuz oldukça anlı şanlı ve mağrur bir armağan idi.

34 Gyulafehérvár (günümüzde Alba lulia, Romanya.)

35 Marzsina (Rumence: Margina.)

36 Belgrad.

37 Zemun, Sirbistan. 


\section{Sultanın Huzuruna Çıkış}

Ertesi gün saat yedide, giysileri, atları, altın ve gümüşler içerisinde parıldayan gösterişli dört yüz asille birlikte prens, sultanın yanına çağıııldı. 0 gün, yani 29 Haziran günü, sultanın huzuruna çıktılar.

\section{Düzen ve Usul}

Ön sırada elli çavuş gidiyordu, ardı sıra başka çavuşlar da vardı. Üçüncü sırada yeniçerilerin ağası, dördüncüde ellerinde gümüş bastonları, fevkalade gösterişli mücevherleri ve atlarıyla teşrifatçı namındaki üç usta, beşincide prensin başlıca dört müşaviri, altıncı sırada ülkenin en önemli dört asili, yedincide, eski geleneklere göre prensin zâtının önünde toy bir kibirle yürüyen, görkemli esvaplar giyinmiş, kuşanmış birkaç tane çocuk, sekizinci sırada ise, üzengisini altın giysilerle donanmış dört adet üzengicinin tuttuğu atılla, kendisine layık bir maiyetle kuşatılmış halde tek başına prens ilerliyordu.

\section{Prensin Ziynetleri, Kıyafeti}

Evvela, prensin uzun ve kurdeleli, astarı sansar kürkünden Macar kalpağına, cevizden daha büyük, değerli bir mücevher olan arma asıldı. İkincisi, boynunda yeni elmas ve eskiden kuyumcuların yüz bin altın değerinde olduğunu tahmin ettiği yakut denilen dört adet güzeller güzeli taşla süslenmiş bir haç vardı. Üçüncüsü, incili altın bir kolye ve kıymetli yüzükler. Dördüncüsü, daha önce sultan tarafından hediye edilen kemerle birlikte ikisi de som altından mamul incili bir kılıç ve hançer. Beşinci, atının, som altından yapılmış, eşi benzeri bulunmayan eyeri. Değeri yirmi beş bin altından fazla olan bu eyer, öyle değerli inciler ve büyük taşlarla parıldamaktaydı ki adeta görenleri kör ediyordu. Altıncısı dizgindi ve atın başı da tamamen incilerle süslenmişti. Yedincisi ise sayıları yüz elliyi bulan büyükçe ve bir o kadar da orta boy inciyle süslenmiş eyer örtüsü.

Düzeni takip ederek, prensin hemen ardından, güzelce donanmış Macar beyleri geliyordu. Yolun ise her tarafı, süvariler ve yeniçerilerle hınca hınç kaplanmıştı. Sultanın ilk çadırına vardıkları vakit prensin attan inip orada biraz dinlenmesine müsaade edildi. Yüce sultana hediyeleri getiren yeniçerilerin de öne çıkıp, armağanları takdim etmelerine izin verildi.

\section{Yüz Yeniçeri Tarafından Sunulan Hediyeler}

Evvela, yuvarlak altın bir kap ya da tabak içerisinde, uygun yerlerinde dört adet elmas, üç adet kıymetli yakut, ortasında ise altı bin altın değerinde muazzam saf zümrüt olan on iki bin alıın değerindeki kolye. İkincisi, başka bir tabakta, içinde her on beş dakikada bir çalan, ayrıca ayın ve gezegenlerin seyrini de gösteren muhteşem bir ustalık eseri küçük bir saatçik bulunan harikulade bir yüzük. Üçüncüsü, elli tane altın kaplamalı büyük gümüş kupa. Dör- 
düncüsü on adet altın kaplamalı gümüş tabak. Beşincisi on iki tane orta boy tabak ve altıncısı çok sayıda daha küçük tabak. Yedincisi, güzel bir tezyinatla süslenmiş altı tane kare fincan. Son olarak birkaç adet, en iyilerinin arasından seçilmiş doğan.

Sultan, hediyelerin şaşaasını görür görmez prensin yanına çağrılmasını emretti. Prens de başlıca dokuz beyi ile beraber, önünde dört paşanın beklediği, incilerle parıldayan altın tahtında sürur içinde oturan hükümdarın çadırına gitti. Ve diz çöküp elini öpmesi için baş paşa (vezir) tarafından süratle sultanın yanına götürüldü. Sultan buna karşılık prense sarılarak "Kıymetli oğlum, gelişin kutlu olsun" dedi ve oturmasını emretti. Prens oturmak istemeyince sultan “ Otur kıymetli evladım” diyerek ısrar etti. Ardından prens sağ tarafa, paşaların durduğu yere, onların ayakları altına oturdu. Bu esnada, prensin yanında getirdiği dokuz kişi de içeri girdi ve farsi geleneğe göre, çavuşların adetleri olduğu üzere, sanki tapar gibi sultanın ayaklarına kapandılar. Törenin ardından biz diğer çadıra geçerken, prens ayağa kalkıp kısaca meselesini beyan etti ve bu meseleyle ilgili sultana küçük bir kitapçık takdim etti. Şimdilik prensin ne söylediği, kitapta bulunan istirhamları ve birbirleriyle ne konuştuklarını aktarmam mümkün olmadığından başka bir sefer detaylı bir biçimde yazacağız. Bununla birlikte, sultanın şunları söylediğinden kesinlikle eminiz: İlk olarak, hiçbir şey prensin, sultanın huzuruna çıkması ve ölene kadar onun himayesi altında kalmasından daha kıymetli olamaz. İkincisi, ölümünden evvel sultanla yüz yüze görüşmesini önerenler hayırlı bir işte bulunmuşlar; prensin bu zahmetleri boşa çıkmayacak ve gelecekte karşılığını bulacaktır. Üçüncüsü, yazılı olarak niyaz ettiği ne varsa kendisine bağışlanacaktır.

Haşmetli prens sultanın ayaklarına eğilerek lütfettikleri için kendisine şükranlarını sundu. Sultan, prensi ayağa kaldırıp, “Kalbin sükunetle dolsun, Allah'ın, salih vasıtalarla yetimlerin, dulların ve terk edilmişlerin her daim yanında olduğunu tüm dünyaya gösteriyorum." Prens, böylesi yüce bir haminin ve koruyucunun lütfuna övgüler yağdırarak, ona Tanrı'dan her türlü mutluluğu dileyerek, geldiği zamanki düzen ve ihtişam içerisinde çadırına geri döndü.

\section{Sultanın Çavuşlarla Yolladığı Hediyeler}

Ertesi gün sultan da yirmi iki çavuş aracılığıyla karşılıklı hediyeler gönderdi. Evvela değerli incilerle bezenmiş bir altın kemer. İkincisi, aynı şekilde süslü bir kılıç ve hançer. Üçüncüsü samur kürklü kaftanlara benzeyen iki adet altınlı elbise. Dördüncüsü, sultanın elini öpenler için altından dokunmuş dokuz adet esvap. Beşincisi, üçü saf altından ve inciden gemleri olan on iki tane Türk atı; atların ikisi üç bin altına daha yeni satın alınmıştı.

Bunların dışında sultanın hazinesinin kilerinden çeşit çeşit baharatlar, ilaçlar ve kıymetli kaplar da bahşedildi. Hediyeleri alan Prens, sultanın ona bahşettiği bu onur için teşekkür etti ve adetlere göre paşalarla diğer baş danışmanlara ziyaret gerçekleştirilmesini ve hediye verilmesini emretti. Burada sultanın mükemmelliğini ve iyi niyetini dile getirmeyi de unutmuyorum. 
Ertesi gün sultan, haşmetli prensi ağırlamak istedi ve her şey hazırlanırken baş paşa (vezir) yüce sultana, "böylesi küçük bir meseleden ötürü çok kötü bir şöhret edinmenizden korkarım" diyerek bu işe girişmemesini önerdi. "Prensin sıhhati iyi gözükmüyor ve Türk yemeklerine de alışık değil. Bu durumda prense bir şey olduğu takdirde tüm hristiyanlar yüce sultanı prensi zehirlemekle itham edebilirler." Sultan bunu işitince ziyafet hazırlıklarını durdurarak prensi haberdar etti. Ve böylece hem prensin hem de Macarların gözünde lanetli bir zan altında kalmaktan kurtulmuş oldu.

Onlar oradayken, haşmetli Fransız kralının elçisinin geldiği gün, prens hazretleri de tabura gitti.

Zira Üstad (dominus) Guilelmus de Aube haber göndererek, eğer müsaadesi olursa, kendi kralı adına prensi selamlamak istediğini bildirmişti. Kendisine izin verildi. Prensin karşısına çıktığı vakit belâgatli sözleriyle birlikte lordunun onuru ve şerefine layık hediyelerini takdim etti. Diğer şeylere ilaveten prensin İncil'i öğrenmesine ve bu bilgileri haiz olup, papalıktan ayrılarak, mükemmelliğe işaret eden doğru yolu takip etmesine çok sevindiğini; duyduğu, gördüğü olayları haşmetli hükümdarına yazmak istediğini bildirdi.

Prens, elçinin gelişinin çok memnuniyet yarattığını söyledi ve ona sahip çıkacaklarına söz veren ülkesinin baş zümrelerine ve haşmetli kralına çok teşekkür etti. illaveten, haşmetli kralın mesajılla ilettiği arkadaşık ve akrabalık bağlarını güçlendirip bu durumu muhafaza etmek için elinden geleni ardına koymayacağını bildirdi. Bu cihetle prens de hemen kendi mektubunu haşmetli kralın huzuruna iletmek istedi. Bu esnada bazı sözler daha söylendi fakat şimdi onları buraya yazmamın lüzumu yok.

\section{Sultanla İkinci Görüşme}

İkinci görüşme, Temmuz'un birinci gününde prens, daha fazla gecikmemek ve Erdelliler arasında kargaşa çıkmasına fırsat vermemek adına, sultandan ayrılmak için müsaade istediği vakit gerçekleşti. Prens, aynı düzen ve maiyetiyle birlikte sultanın yanına gitti fakat daha önce giydiklerinin hiçbiri yeniden gözükmesin diye yeni klık kıyafetler hazırlattı. Dile getirilmesi bile inanılmaz olsa da prens, sultanın müstakbel inayetinden açıkça bahsedip, ona olan minnetini ve şükranlarını ifade ettiği sırada, sultan tahtından kalkıp diğerleri arasında ona sarılarak, "Bizden arzu ettiğin şeyleri alabildin mi?" dedi. Prens aldığını söyleyince "Bizi düşmanlarımıza karşı galip ve muzaffer kılması için Allah'a yakar. Çünkü seni şimdiki halinden üç kat daha kuvvetli kılmaya hazırız." diye ekledi. İhtiyar fakat kudretli sultan o gün, tahtından iki defa kalkarak prensi "sevgili oğlum" diyerek kucakladı.

\section{Sultanın Prense İade Ettikleri}

Prens ise diğerlerine ilaveten Körös Nehri ve Erdel arasındaki, şehir, şato ve iki binden fazla köy bulunan vilayeti istedi. Paşalar daha önceden, oralarda Türklere mescitler inşa 
edildi diye uyarınca Temeşvar'ı ya da Lippa'yı söz konusu bile etmedi. Bunlardan sonra, Debrecen ve Szolnok arasındaki hududu istedi. Sultan, hiç karşı çıkmadan buraları kendisine bahşetti. Bunun dışında üç yüz esir serbest bırakıldı ve ona hizmet edenlere yüksek mevkiler bahşedildi.

Dahası, Sultan artık vedalaşmak istediği vakit herkesi gönderdi ve prensin Türk tercümanının yardımıyla bir süre ötekilerden ayrı sohbet ettiler. İkisinin neler konuştuğu bu zamana dek hala bilinmiyor.

Sultan gitmeden evvel prense en kısa zamanda ailesine, ordularına ve askerlerine mektup göndererek onları bahşedilen inayetten haberdar etmesini ve inandıkları yolda ilerlemekten vazgeçmemelerini salık verdi. İlaveten Alman taraftarı olan Macarlara göndereceği mektupta, en kısa zamanda tabura gelerek ona sadakatlerini sunmalarını da bildirmeliydi. Bunu yaptıkları takdirde onların variyetlerinin zeval görmemesi için sultan da çaba gösterecekti.

Prensin hatırı için Macaristan'da ikamet ettikleri zaman zarfında baş zümrelere aylık ödenecek ve bu bir yemin ve bu meselelerle ilgili genellikle verilen bir mektupla tasdik edilecek aksi halde yeri göğü alt üst eden Tatarlar gönderilecekti.

Sultan bu karar hayırla kabul olsun diye daha büyük sözler verip, yüksek tabakaya ait olan mühim Macar beylerine prense boyun eğmeleri için elçiler gönderdi. Bu kısa zaman içinde sudur eden mahvın müsebbibinin kendi olmadığına, suçun onların inatları, kötülükleri ve itaatsizliklerinden kaynaklandığını Allah'ın önünde şahitlik ettiğini söyledi.

Bu ve buna benzer şeyler sultanın meseleye karşı çok hassas olduğunu ve bu hususta çok emek verdiğini gösteriyordu. "Halkın, topun, mermin, barutun yeterli mi bak. Azaldığı vakit bana haber ver, istediğini göndereceğim." diye de ekledi.

Nihayetinde prens, sultanı bırakıp, aynı gurur ve ihtişamla nehrin kıyısına geri dönerek orada bütün baş zümrelere teşekkürlerini sundu. Maiyetiyle beraber sultanın gemisi ile geri götürülüp ordugahına sağ salim ulaştı ve 17 Temmuz'da alelacele Fejérvár'a gitti. Orada ayın yirmi sekizinci gününe kadar meclisini toplamakla uğraşınca, topların çekilmesinde ve azığın dağıtıımasında gecikti. Nihayet o gün, prens halkının Kolozsvár ${ }^{38}$ yakınlarına kurduğu ordugaha geçti, o zamana kadarsa kaybettiklerini tazmin etmekle meşguldü.

38 Koloşvar (günümüzde Cluj-Napoca, Romanya) 
Prensle birlikte, çadırda Türk sultanının huzurunda olanların adları: Mihály Csáky ${ }^{39}$, Gáspár Bekes $^{40}$, Gergely Apaffy ${ }^{41}$, György Kapitány ${ }^{42}$, Gergely Bánffi ${ }^{43}$, Miklós Telegdi ${ }^{44}$, Farkas Bornemisza ${ }^{45}$, Pál Bég ${ }^{46}$, Mihály Telegdii" ${ }^{47}$ Szeben şehri beyi ${ }^{48}$, Orbán Miklós ${ }^{49}$, ve Doktor Blandráta ${ }^{50}$.

39 Mihály Csáky (1505-1572) 1539 ylında Gyulafehérvár kanonu (canon), 1549'da Hunyad'da başrahiplik görevlerinde bulundu. Aynı zamanda Kraliçe Isabella'nın da sekreteriydi. 1556 yılından ölümüne kadar János Zsigmond'un şansölyesi (kancellar) görevini sürdürmüştür. Bkz. a.g.e., 63. dipnot, s. 150. Ayrıca Csáky Ailesi için bkz. Magyarország családai czimerekkel és nemzékrendi táblákkal, https://www.arcanum.hu/hu/online-kiadvanyok/ Nagyivan-nagy-ivan-magyarorszag-csaladai-1/harmadik-kotet-1435/csaky-csalad-keres-szeghi-grof-1644/ , (erişim 27 Şubat 2019).

40 Gáspár Bekes (1520-1579) kariyerine János Zsigmond'un naibi ve başta gelen danışmanlarından biri olan Péter Petrovics'in yanında başladı. Ardından Zsigmond'un en etkili danışmanı ve 1560 yılından itibaren de hazinedarı oldu. János Zsigmond'un vefatını ardından Erdel Voyvodalığı için István Báthory ile bir mücadeleye girişti. Bu dönemde Maximilian ve Sekeller ile ittifak kurarak Báthory'e karşı iki ayaklanma gerçekleştirdi ancak ikisinde de mağlup oldu. Bkz. a.g.e., 64. dipnot, s. 150

41 Gergely Apaffy (? -1584) 1551 yilından önce Doboka idari bölgesinin yöneticisi (vármegye főispánja) ve György Martinuzzi'nin de vekiliydi. Daha sonra Kraliçe Isabella'nın ve János Zsigmond'un baş vekilliğine terfi edildi (föudvarmester). Kraliyet danışmanları arasındaydı. Bkz. a.g.e., 65. dipnot, s. 150 Ayrıca Apaffy Ailesi için bkz. Magyarország családai czimerekkel és nemzékrendi táblákkal, https://www.arcanum.hu/hu/online-kiadvanyok/ Nagyivan-nagy-ivan-magyarorszag-csaladai-1/elso-kotet-2/apaffy-csalad-apa-nagyfalvi-182/ , (erişim 27 Şubat 2019).

42 György Kapitány (?-1566) 1556 yılında Várad kuşatması sırasında Habsburg İmparatorluğu kumandanı, 15621565 yılları arasında yaşanan karışıklar sırasında da sıklıkla Türkler ve János Zsigmond ile çatışmalara giren Simon Forgách'a esir düştü. Serbest kalmasının ardından da János Zsigmond'a hizmet etmeye devam etti. Sultan Süleyman ile yapılan görüşmeden kısa bir süre sonra Tokaj'da kuşatması sırasında hayatını kaybetti. Bkz. a.g.e, 66. dipnot, s. 151.

43 Losonczy Bánffy György. (?-1573) János Zsigmond'un danışmanlarından biridir. Kristóf Báthory zamanında baş kumandanlığa terfi edilmiştir. Bkz. a.g.e., 67. dipnot, s. 150.

44 Miklós Telegdi (1535-1586) János Szapolyai'nin ölümünün ardından István Maylád'ın tarafına geçti. Bu yüzden haklarına el konulmuştu ancak János Zsigmond'un hakimiyetini tanıyınca toprakları ve hakları iade edildi. 1562 yılında yaşanan çatışmalar sırasında Balassa Menyhért'e (ki kendisi Habsburg Imparatorluğu ve Erdel Prensliği arasında sık sık taraf değiştirmiştir. Bu dönemde Habsburg yanlısı olan Menyhért Tokaj'daki şarap bağlarının hasadına el koymuş ve bir anlamda yaşanan çatışmaların tetikleyicisi olmuştur) esir düşmüştür. 1579 yılında Pécs Piskoposu olmuş fakat Türk işgallerinden ötürü görevini icra edememiştir. 1582 yilından ölümüne kadar Esztergom baş piskoposluğu yapmıştır. Bkz. a.g.e., 68. dipnot, s. 151. Ayrıca Telegdi Ailesi için bakınız: Magyar életrajzi lexikon, http://mek.oszk.hu/00300/00355/html/index.html, (erişim 27 Şubat 2019).

45 Farkas Bornemisza (?-1572) 1560'lı yıllarda prensin danışmanları arasındaydı. Gençlik yıllarında Türklere karşı savaşmış ve esir düşmüş fakat daha sonra Sultan Süleyman tarafından János Szapolyai'e teslim edilmiştir. 1562 ylında Şansölye Mihály Csáky, Balassa Menyhért karşısında askeri yardım talep etmesi için onu Buda'ya elçi olarak göndermiştir. 1563 ylında Fehér bölgesinin yöneticisi olmuştur. Bkz. a.g.e., 69. dipnot, s. 151

46 Pál Bég (-) Sekel komutanı. 1571 yılında István Báthory taraftarı olmuş ve kendisine Lehistan'a Kral olarak gittiği vakitte eşlik etmiştir. Bkz. a.g.e., 70. dipnot, s. 151

47 Mihály Telegdi (?-1588) Miklós'un kardeşi. 1569 ylında Sekellerin başkumandanı ve Székelyudvarhely (günümüzde Odorheiu Secuiesc, Romanya) kale kumandanı olmuştur. János Zsigmond'un vefatından sonra voyvodalık çekişmesinde Gáspár Bekes'in tarafında yer almıştır. Bkz. a.g.e., 71. dipnot, s. 151.

48 Simon Miles. (Nagyszeben, günümüzde Sibiu, Romanya) Bkz. a.g.e., 72. dipnot, s. 151.

49 Orbán Miklós 1568 yılında Erdel haracını ödemek için İstanbul'a gitmiş olması dışında başka bir detaya rastlanmamaktadır. Bkz. a.g.e., 73. dipnot, s. 151.

50 György Blandráta (Biandrata) (1515-1588) İtalyan asıllı bir doktor. 1563 yilında Kraliçe İsabella'nın hizmetine girmiştir. János Zsigmond'un hem doktoru hem de danışmanlarından biridir. Prensin vefatının ardından haleflerinin hizmetlerinde çalışmaya devam etmiştir. Bkz., a.g.e., 74. dipnot. s. 151. 
İbretlerle yaşamayı bilenlere veya yaşamak isteyenlere bunlar birer misal olsun.

İsa'dan sonra 1566.

Hakem Değerlendirmesi: Dış bağımsız.

Çıkar Çatışması: Yazar çıkar çatışması bildirmemiştir.

Finansal Destek: Yazar bu çalışma için finansal destek almadığını beyan etmiştir.

Peer-review: Externally peer-reviewed.

Conflict of Interest: The author has no conflict of interest to declare.

Grant Support: The author declared that this study has received no financial support.

\section{Bibliyografya/Bibliography}

\section{Arşiv Belgeleri}

5 Numaralı Mühimme Defteri (973/1565-1566) -Tıpkıbasım-. Ankara: T.C. Başbakanlık Devlet Arşivleri Genel Müdürlüğü, 1994.

Feridun Ahmed Bey. Mecmua-i Münşeatü's-selatin. 2 Cilt. İstanbul: 1848-1858, https://acikerisim.tbmm. gov.tr/xmlui/handle/11543/588, (erişim 23 Mayıs 2019).

Procházka-Eisl, Gisela ve Römer, Claudia. Osmanische Beamtenschreiben und Privatbriefe der Zeit Süleymāns des Prächtigen aus dem Haus-, Hof- und Staatsarchiv zu Wien. Wien: Verlag der Österreichischen Akademie der Wissenschaften, 2007.

Schaendlinger, Anton C. ve Römer, Claudia. Die Schreiben Süleymâns des Prächtigen an Karl V., Ferdinand I. und Maximilian II. aus dem Haus, Hof- und Staatsarchiv zu Wien. Wien: Verlag der Österreichischen Akademie der Wissenschaften, 1983.

Schaendlinger, Anton C. ve Römer, Claudia. Die Schreiben Süleymans des Prächtigen an Vasallen, Militärbeamte, Beamte und Richter aus dem Haus-, Hof- und Staatsarchiv zu Wien. Wien: Verlag der Österreichischen Akademie der Wissenschaften, 1986.

\section{Kronikler}

Başpınar, Fatih. “Kanuni Sultan Süleyman'ın Son Seferine Dair Bir Mesnevi: Merâhî’nin “Fethnâme-i Sefer-i Sigetvar" Adlı Eser." Dede Korkut Türk Dili ve Edebiyatı Araştırmaları Dergisi II/4 (2013): 18-74.

Bessenyei József (ed.). Zay Ferenc: János király árultatása. Kis Péter: Magyarázat.[Bánffy György]: Második János ... török császárhoz menetele. Budapest: Balassi Kiadó, 1993.

Ferenc Forgách. Emlékirat Magyarország állapotáról Ferdinánd, János, Miksa királysága és II. János erdélyi fejedelemsége alatt. çev. Borzsák István, Budapest: Szépirodalmi Könyvkiadó, 1982.

Feridun Ahmed Bey. Sultan Süleyman'ın Son Seferi. Nüzhet-i Esrârül-Ahyâr Der-Ahbâr-ı Sefer-i Sigetvar. haz. H. Ahmet Arslantürk ve Günhan Börekçi, İstanbul: Zeytinburnu Belediyesi Kültür Yayınları, 2012.

Naç, Kübra. “Âgehî’nin Fetih-nâme-i Kal'a-i Sigetvar'ı (İnceleme-Tenkitli Metin).” Yayınlanmamış Yüksek Lisans Tezi, Fatih Üniversitesi, 2013.

Selânikî Mustafa Efendi. Tarih-i Selânikî. haz. Mehmet İpşirli, İstanbul: İstanbul Üniversitesi Edebiyat Fakültesi, 1989. 


\section{İkincil Literatür}

Ertuğ, Zeynep Tarım. “Minyatürlü Yazmaların Tarihî Kaynak Olma Nitelikleri ve Nüzhetü’l-Esrâr.” Tarih Boyunca Türk Tarihinin Kaynakları Semineri 6-7 Haziran 1996 Bildiriler içinde 31-46. İstanbul: İstanbul Üniversitesi Edebiyat Fakültesi, 1997.

Fodor, Pál ve Szabolcs, Varga. “Zrínyi Miklós és Szulejmán halála." Történelmi Szemle, MTA Bölcsészettudományi Kutatóközpont - Történettudományi Intézet, Vol: 2 içinde 181-201, Budapest: 2016.

Fodor, Pál, The Unbearable Weight of Empire: The Ottomans in Central Europe - a Failed Attempt at Universal Monarchy (1390 - 1566). Budapest: Research Centre for the Humanities, Hungarian Academy of Sciences, 2015.

Fodor, Pál (ed.). The Battle for Central Europe. The Siege of Szigetvár and the Death of Süleyman the Magnificent and Nicholas Zrínyi (1566). Leiden-Boston: Brill; Budapest: Hungarian Academy of Sciences Research Centre for the Humanities, 2019.

Gökbilgin, Tayyip. “Kanuni Süleyman'ın 1566 Szigetvar Seferi Sebepleri ve Hazırlıkları.” Tarih Dergisi 21 (1966): 1-14.

. “Nagy Szoliman 1566. evi Szigetvar elleni hadjaratanak elözmenyei." Szigetvari emlekkönyv. Szigetvár 1566. évi ostromának évfordulójára içinde s. 53-59. Budapest: Akadémiai Kiadó, 1966.

. Kanuni Sultan Süleyman. İstanbul: Trakya Üniversitesi 2016.

Kenyeres, Ágnes. Magyar életrajzi lexikon. http://mek.oszk.hu/00300/00355/html/index.html , (erişim 27 Şubat 2019).

Kolçak, Özgür. "Sınır Diplomasisinden Saltanat Elçiliğine: Bir 16. Yüzyil Diplomasi Hikâyesi Yahut Marcus Scherer/Hidayet'in Esrarli Sergüzeşti." Tarih Araştırmaları Dergisi 39 (2020): 139-214.

Majláth, Béla. A Majláth-család nemzedékrendje (négy rajzzal), https://www.arcanum.hu/hu/onlinekiadvanyok/Turul-turul-1883-1950-1/1888-435B/1888-1-435C/1a-majlath-csalad-nemzedekrendjenegy-rajzzal-4364/, (erişim 27 Şubat 2019).

Iván, Nagy ve István, Friebeisz. Magyarország családai Czimerekkel és nemzékrendi táblákkal. 1988, https://www.arcanum.hu/hu/online-kiadvanyok/Nagyivan-nagy-ivan-magyarorszag-csaladai-1/ otodik-kotet-356E/hagymassy-csalad-szent-girothi-es-beregszoi-35D5/, (erişim 27 Şubat 2019).

Norbert, Pap (ed.). Szülejmán Szultán emlékezete Szigetváron/Kanuni Sultan Süleyman'ın Sigetvar'daki hatırası. Pécs: Mediterrán és Balkán Fórum,VIII. évfolyam, 2014.

Parladır, Şebnem. “Sigetvar Seferi Tarihi ve Nakkaş Osman.” Sanat Tarihi Dergisi XVI/1 (2007): 67-108.

Petri, Mór. Szilágy vármegye monographiája: Szilágy vármegye törvényhatosági bizottságának megbizásából. 1901, http://mek.oszk.hu/04700/04750/html/143.html , (erişim 27 Şubat 2019).

Tracy, James. "The Road to Szigetvár: Ferdinand I's Defense of His Hungarian Border, 1548-1566." Austrian History Yearbook 44 (2013): 17-36.

Varga, Szabolcs. Europe's Leonidas: Miklós Zrínyi, Defender of Szigetvar (1508 - 1566). çev. David Robert Evans. Budapest: Magyar Tudományos Akadémia Bölcsészettudományi Kutatóközpont, 2016.

Yurdaydın, Hüseyin Gazi. "Sigetvarnâmeler." Ankara Üniversitesi Ilahiyat Fakültesi Dergisi II-III (1952): 124-136.

Wertheimer, Eduard. "Zur Geschichte des Türkenkrieges Maximilians II. 1565 und 1566." Archiv für österreichische Geschichte 53 (1875): 43-101. 